\title{
Relasi Antara Supervisi Dengan Kualitas Pendokumentasian dalam Asuhan Keperawatan
}

\author{
Nikita Gina Chesena Sembiring \\ nikitagina.ng@gmail.com
}

\section{LATAR BELAKANG}

Manajemen keperawatan adalah terlaksananya Asuhan Keperawatan yang bermutu kepada pasien. Pelaksanaan manajemen keperawatan didukung kemampuan dan keterampilan kepemimpinan dalam pelayanan keperawatan yang efektif dan efisien oleh setiap perawat baik sebagai staf, ketua tim, kepala ruang, pengawas atau kepala bidang (Swanburg,Rc.2000). Melaksanakan peran perawat dalam memberikan asuhan keperawatan akan dilihat dari kinerja perawat melalui pengamatan langsung yaitu proses pemberian asuhan keperawatan atau catatan pasien (dokumentasi) asuhan keperawatan yang telah diberikan. Dalam melaksanakan perannya biasanya perawat dilandasi oleh adanya motivasi dan kemampuan dalam memberikan asuhan keperawatan.

Dalam teori motivasi menurut Frederick Herzberg yang dikenal dengan teori dua faktor menjelaskan bahwa ada dua faktor yang mempengaruhi motivasi seseorang dalam melaksanakan pekerjaan yaitu faktor motivator dan faktor higienis. Dalam pelaksanaan asuhan keperawatan diperlukan pengarahan dan pengawasan melalui kegiatan supervisi. Kepala ruang memegang peran penting dalam supervisi dan merupakan manajer yang bertanggung jawab terhadap perawat pelaksana, sehingga dapat meningkatkan kualitas Asuhan Keperawatan yang diberikan dan akhirnya dapat meningkatkan kinerja perawat pelaksana.

Supervisi adalah kegiatan yang dilakukan berdasarkan keterampilan dan disengaja dalam pelaksanaan supervisi agar tujuan dan kualitas refleksi dan pembelajaran terjadi (Davys, 2010). Supervisi adalah suatu proses kemudahan untuk menyelesaikan tugas-tugas keperawatan (Swanburg \& Swansburg, 1999). Supervisi yang efektif dibagi atas tiga pilar yaitu pengawasan pemeriksaan dan pendidikan. Setiap pilar bergantung dan berkontribusi terhadap yang lain secara sinergis, baik untuk meningkatkan dan mengurangi proses supervisi (Falender, 2004). 
Seorang supervisor keperawatan dalam menjalankan tugasnya sehari-hari harus memiliki kemampuan yaitu memberikan pengarahan dan petunjuk yang jelas sehingga dapat dimengerti oleh staf dan pelaksana keperawatan, memberikan saran, nasehat dan bantuan kepada staf dan pelaksana keperawatan, memberikan motivasi untuk meningkatkan semangat kerja, memberikan pelatihan dan bimbingan yang diperlukan oleh pelaksana keperawatan, melakukan penilaian terhadap penilaian kinerja perawat mengadakan agar Asuhan Keperawatan yang diberikan lebih baik.

Manajer keperawatan atau kepala ruang memiliki tanggung jawab dalam pelaksanaan asuhan keperawatan yang efektif serta aman kepada pasien dan memberikan kesejahteraan fisik emosional dan kedudukan bagi perawat. Pelaksanaan supervisi bukan hanya ditujukan untuk mengawasi Apakah seluruh staf keperawatan menjalankan tugasnya dengan sebaikbaiknya, sesuai dengan instruksi atau ketentuan yang telah digariskan, tetapi juga bagaimana memperbaiki proses keperawatan yang sedang berlangsung. Kegiatan supervisi yang baik menjadikan seluruh staf keperawatan bukan sebagai objek tetapi juga sebagai subjek. Perawat diposisikan sebagai mitra kerja yang memiliki ide-ide pendapat, dan pengalaman yang perlu didengar, dihargai dan diikutsertakan dalam melakukan asuhan keperawatan.

Dokumentasi didefinisikan sebagai segala sesuatu yang tertulis atau tercetak yang dapat diandalkan sebagai catatan dengan bukti bagi individu yang berwenang (Potter dan Perry, 2002). Dokumentasi merupakan bagian integral proses keperawatan, bukan sesuatu yang berbeda dari metode problem solving. Pendokumentasian asuhan keperawatan merupakan bagian penting dalam pemberian pelayanan kesehatan di Rumah Sakit, dan setiap pelaksanaannya tidak jauh dari 5 proses keperawatan yang meliputi pengkajian, diagnosa intervensi implementasi dan evaluasi (Prabowo, 2017; Potter dan Perry, 2010).

Faktor yang mempengaruhi kelengkapan pendokumentasian asuhan keperawatan mengadopsi dari teori perilaku dan kinerja (Donnely Jr, 1997) yaitu: faktor individu: kemampuan keterampilan, latar belakang keluarga dan demografi seseorang. Faktor psikologis: persepsi, sikap, kepribadian, motivasi. Faktor organisasi: sumber daya, supervisi, imbalan struktur, beban kerja.

Pengawasan yang efektif akan meningkatkan pelaksanaan dokumentasi asuhan keperawatan titik pengawasan menjadi pengaruh utama dalam pendokumentasian asuhan keperawatan untuk meningkatkan hasil kinerja perawat. Dengan adanya pengawasan dapat 
menjadikan perawat lebih disiplin dalam mengisi kelengkapan asuhan keperawatan (Handoyono \& Hartati, 2010).

\section{METODE}

Kajian ini dilakukan dengan metode menganalisis dari berbagai sumber bacaan. Baik dari berbagai jurnal online, buku ataupun e-book, yang memiliki hubungan dengan pendokumentasian dalam keperawatan.

Penulisan kajian ini melakukan metode perbandingan antar satu artikel dengan artikel lainnya. Kemudian perbandingannya ditulis secara beraturan dalam hasil dari kajian. Dengan isi yang akan dibandingkan tetap berhubungan dengan pendokumentasian dalam keperawatan.

\section{HASIL}

Hasil dari beberapa sumber yang didapat baik dari jurnal online, skripsi. Ditemukan bahwa pengaruh supervisi terhadap kelengkapan pendokumentasian asuhan keperawatan mengungkapkan adanya hubungan antara supervisi kepala ruangan dengan kelengkapan pendokumentasian asuhan keperawatan.

Berdasarkan penelitian menurut Elis Anggeria dan Maria (2018), mengemukakan bahwa terdapat hubungan supervisi dengan pelaksanaan asuhan keperawatan. Supervisi berperan untuk mengarahkan, membimbing dan mengobservasi (pengawasan) pelaksanaan asuhan keperawatan. Dalam penelitian penelitian menyebutkan bahwa kepala ruang belum optimal dalam melakukan pengawasan terkait evaluasi terhadap pendokumentasian asuhan keperawatan (Anggaria, Elis; Maria, 2018).

Menurut Ariyanti (2015) dalam jurnal "Pengaruh Supervisi Ketua Tim terhadap Kelengkapan Pendokumentasian Asuhan Keperawatan Di RSUD Ambarawa” dinyatakan terdapat pengaruh dari kepala ruang sebagai supervisi. Sebelum dilakukan pengawasan terdapat ketidaklengkapan dokumen asuhan keperawatan pada pengkajian kurang lengkap 93,8\%, dokumentasi diagnosa kurang lengkap sebanyak 87,5\%, intervensi kurang lengkap sebanyak 90,6\%, implementasi kurang lengkap 93,8\% dan 87,5\% kurang lengkap pada dokumentasi kurang lengkap. Sedangkan setelah dilakukan pengawasan oleh kepala ruang pendokumentasian asuhan keperawatan menjadi lebih lengkap. Oleh karena itu kepala ruang yang melakukan pengawasan yang baik akan meningkatkan kelengkapan pendokumentasian asuhan keperawatan. 
Menurut Rostiani, dkk (2008) dalam penelitiannya mengungkapkan adanya hubungan supervisi kepala ruang berdasarkan kelengkapan pendokumentasian asuhan keperawatan dengan hasil menunjukkan bahwa adanya perawat yang mempunyai persepsi kurang baik terhadap pengawasan serta angka kelengkapan pendokumentasian asuhan keperawatan yang dilakukan kurang baik. Dalam penelitian ini dikatakan hal yang paling berpengaruh terhadap kelengkapan pendokumentasian asuhan keperawatan adalah pengawasan (Dewi, Yetti, \& Ayubi, 2008).

Menurut penelitian Dita, dkk (2014), pengawasan yang dilakukan kepala ruang akan meningkatkan kinerja dan mencapai suatu tujuan yang ditetapkan. Namun, apabila pengawasan tidak dilakukan dengan optimal maka akan terjadi penurunan motivasi perawat yang mengakibatkan pekerjaan semakin lebih lambat selesai, terlambat datang, kepuasan kerja yang menurun, dan adanya keluhan pasien mengenai pelayanan yang kurang memuaskan. Selain itu kinerja perawat-perawat akan menurun dan terjadi pelayanan keperawatan yang kurang berkualitas yang dapat mempengaruhi nama baik dari institusi pelayanan kesehatan seperti rumah sakit.

Hasil penelitian yang dilakukan oleh Huton dan Gates (2008), menyatakan bahwa kepuasan dengan supervisor berhubungan positif dengan produktivitas kerja. Menurut Wegman dan McGee dalam Ledvak dan Buck (2008), perawat yang kurang terlatih adalah masalah yang signifikan yang mempengaruhi produktivitas kerja. Untuk mengatasi hal ini, manajer atau kepala ruangan ataupun supervisor diharapkan mampu melaksanakan perannya sebagai perencana, pelatih, pengarah dan mengevaluasi serta sebagai role model yang dapat dilakukan pada saat pelaksanaan supervisi.

Hal ini dibuktikan dengan penelitian dari (Pantintingan, Pasinringi, \& Anggraeni, n.d.) Gambaran Motivasi Kerja Perawat di Ruang Rawat Inap Rumah Sakit Universitas Hasanuddin Makassar. Diperoleh data bahwa motivasi kerja perawat rawat inap Rumah Sakit Unhas, terkait dengan supervisi memiliki persentase (83.1\%). Penelitian tersebut menunjukkan bahwa dengan diadakannya supervisi pimpinan maka perawat termotivasi untuk meningkatkan kinerja mereka.

Penelitian yang dilakukan Leli Siswana (2010) tentang hubungan peran supervisi kepala ruangan terhadap kinerja perawat pelaksana di Rumah Sakit Umum Daerah Petala Bumi didapatkan bahwa Peran supervisi kepala ruangan yang sangat baik sebanyak 21 orang 
$(16,2 \%)$, persentase ini ternyata lebih tinggi dari pada peran supervisi kepala ruangan yang kurang baik sebanyak 10 orang $(14,8 \%)$.

Hal ini sejalan dengan penelitian yang dilakukan oleh Wiyanti (2009), tentang Hubungan Peran Supervisi Kepala Ruangan dengan Kinerja Perawat Pelaksana Asuhan Keperawatan di Instalasi Rawat Inap yang dilakukan terhadap 67 orang perawat pelaksana di rawat inap diperoleh hasil bahwa ada hubungan yang bermakna antara peran supervisi kepala ruangan dengan kinerja perawat pelaksana.

Dan hasil penelitian oleh Putra Ardi Wibowo Tahun 2012 yang berjudul Hubungan Pelaksanaan Supervisi Kepala Ruangan Terhadap kinerja Perawat dalam Pendokumentasian Asuhan Keperawatan di RST Wijayakusuma Purwokerto. Hasil analisis dengan menggunakan uji statistik chisquare dari 56 responden katagori pelaksanaan supervisi baik terlihat hasil uji statistik didapatkan nilai $\mathrm{p}$ value $=0,011$ berarti $\mathrm{p}$ value $<0,05$, sehingga dapat disimpulkan bahwa terdapat hubungan yang bermakna antara pelaksanaan supervisi dengan kinerja perawat pelaksana dalam pendokumentasian asuhan keperawatan.

\section{PEMBAHASAN}

Keperawatan adalah bentuk pelayanan professional yang menjadi bagian integral dari pelayanan kesehatan, didasarkan pada ilmu dan kiat keperawatan. Keberhasilan pelayanan keperawatan sangat dipengaruhi oleh manajer keperawatan dalam melaksanakan peran dan fungsinya. Fungsi manajerial yang menangani pelayanan keperawatan di ruang perawatan dikoordinasi oleh Kepala ruang. Salah satu fungsi manajerial kepala ruang yang harus dijalankan adalah fungsi pengawasan melalui supervisi.

\section{- Supervisi}

\section{A. Pengertian Supervisi}

Supervisi merupakan upaya yang dilakukan oleh seseorang untuk diangkat dalam suatu organisasi untuk melakukan pembinaan, bimbingan, atau pengawasan oleh pengelola program terhadap pelaksana di tingkat administrasi yang lebih rendah dalam rangka menetapkan kegiatan sesuai dengan maksud dan sasaran yang telah ditetapkan (Muninjaya, 2012).

Supervisi merupakan bagian yang penting dalam manajemen keperawatan. Pengelolaan asuhan keperawatan membutuhkan kemampuan manajer keperawatan dalam melakukan supervisi. Supervisi adalah merencanakan, mengarahkan, pembimbing, mengobservasi, 
dukungan, dan mengevaluasi secara terus-menerus pada setiap perawat dengan adil dan bijaksana.

\section{B. Tujuan Supervisi}

Tujuan utama supervisi adalah untuk lebih meningkatkan kinerja bawahan bukan untuk mencari kesalahan (Hastuti, 2014). Menurut Swanburg dan Swansburg (1990) menyatakan bahwa tujuan supervisi keperawatan antara lain meningkatkan kemampuan pekerjaan melalui orientasi, pelatihan dan bimbingan individu sesuai kebutuhannya serta mengarahkan kepada kemampuan keterampilan keperawatan.

Tujuan supervisi adalah untuk meningkatkan kemampuan pihak yang disupervisi agar mereka dapat melaksanakan tugas kegiatan yang telah ditetapkan secara efisien dan efektif. Manfaat dan tujuan supervisi diantaranya adalah sebagai berikut (Azwar 2010; Suarli dan Bahtiar 2009) :

1. Supervisi dapat meningkatkan efektivitas kerja. Peningkatan efektivitas kerja ini erat hubungannya dengan peningkatan pengetahuan dan keterampilan bawahan, serta makin terbinanya hubungan dan suasana kerja yang lebih harmonis antara atasan dan bawahan.

2. Supervisi dapat lebih meningkatkan efisiensi kerja. Peningkatan efisiensi kerja ini erat kaitannya dengan makin berkurangnya kesalahan yang dilakukan bawahan, sehingga pemakaian sumber daya seperti tenaga harta dan sarana yang sia-sia dapat dicegah.

\section{Prinsip Pokok dalam Supervisi}

(Suarli \& Bachtiar, 2009) prinsip pokok supervisi secara sederhana adalah sebagai berikut:

a. Tujuan utama supervisi ialah untuk lebih meningkatkan kinerja bawahan, bukan untuk mencari kesalahan. Peningkatan kinerja ini dilakukan dengan melakukan pengamatan langsung terhadap pekerjaan bawahan, untuk kemudian apabila ditemukan masalah, segera diberikan petunjuk atau bantuan untuk mengatasinya.

b. Sejalan dengan tujuan utama yang ingin dicapai, sifat supervisi harus edukatif dan suportif, bukan otoriter. Supervisi harus dilakukan secara teratur atau berkala. Supervisi yang hanya dilakukan sekali bukan servis yang baik.

c. Supervisi harus dapat dilaksanakan sedemikian rupa sehingga terjalin kerjasama yang baik antara atasan dan bawahan. 
d. Strategi dan tata cara supervisi yang akan dilakukan harus sesuai dengan kebutuhan masing-masing bahan secara individu.

e. Supervisi harus dilaksanakan secara fleksibel dan selalu disesuaikan dengan perkembangan.

\section{Pelaksana Supervisi}

Menurut Azwar 2010 yang bertanggung jawab dalam melaksanakan supervisi adalah atasan yang memiliki kelebihan dalam organisasi. Menurut Suyanto (2009); Suarli dan Bachtiar (2009) supervisi dalam keperawatan dapat dilaksanakan oleh bagian yang bertanggung jawab, yaitu:

a. Kepala ruangan. Kepala ruangan mengawasi perawat pelaksana dalam memberikan asuhan keperawatan baik secara langsung maupun tidak langsung sesuai dengan metode penugasan yang diterapkan di ruang perawatan tersebut.

b. Pengawas perawatan atau supervisor.

c. Kepala Bidang keperawatan. Sebagai top manajer dalam keperawatan, Kepala Bidang keperawatan bertanggungjawab melakukan supervisi baik secara langsung atau tidak langsung melalui para pengawas keperawatan.

\section{E. Kompetensi Supervisor Keperawatan}

Menurut Suyanto (2009), seorang supervisor keperawatan dalam menjalankan tugasnya sehari-hari harus memiliki kemampuan dalam:

a. Memberikan pengarahan dan petunjuk yang jelas sehingga dapat dimengerti oleh staf dan pelaksana keperawatan

b. Memberikan saran, nasehat dan bantuan kepada staf dan pelaksana keperawatan

c. Memberikan motivasi untuk meningkatkan semangat kerja kepada staf dan pelaksana keperawatan

d. Mampu memahami suatu proses kelompok atau dinamika kelompok.

e. Memberikan latihan dan bimbingan yang diperlukan oleh staf dan pelaksana keperawatan

f. Melakukan penilaian terhadap penampilan kinerja perawat dan

g. Mengadakan pengawasan agar Asuhan Keperawatan yang diberikan lebih baik. 


\section{F. Model Supervisi Keperawatan}

Beberapa model supervisi dapat diterapkan dalam kegiatan supervisi antara lain menurut Suyanto (2009):

a. Model konvensional. Model supervisi dilakukan dengan inspeksi langsung untuk menemukan masalah dan kesalahan dalam pemberian asuhan keperawatan titik model ini dilakukan untuk mengoreksi kesalahan dan memata-matai staf yang sedang mengerjakan tugas. Model ini sering tidak adil karena hanya melihat sisi negatif dari pelaksanaan yang dilakukan oleh perawat pelaksana.

b. Model ilmiah. Supervisi dilakukan dengan pendekatan yang sudah direncanakan sehingga tidak hanya mencari kesalahan atau masalah saja. Karakteristik pada model ini yaitu: dilakukan secara berkesinambungan, sesuai prosedur, instrumen dan standar supervisi yang baku menggunakan data yang objektif sehingga dapat diberikan umpan balik dan bimbingan.

c. Model klimis. Pada model klinis ini bertujuan untuk membantu perawat pelaksana dalam mengembangkan profesionalisme sehingga penampilan dan kinerja nya dalam memberikan asuhan keperawatan dapat meningkat.

d. Model artistik. Supervisi dengan model ini dilakukan dengan pendekatan personal untuk menciptakan rasa aman sehingga supervisor dapat diterima oleh perawat pelaksana yang disupervisi. Sehingga tercipta hubungan saling percaya antara perawat dan supervisor dan mempermudah proses supervisi.

\section{- Pendokumentasian}

\section{Pengertian Pendokumentasian}

Dokumentasi secara umum merupakan suatu catatan otentik atau semua warkat asli yang dapat dibuktikan atau dijadikan bukti dalam persoalan hukum, sedangkan dokumentasi keperawatan merupakan bukti pencatatan dan pelaporan yang dimiliki perawat dalam melakukan catatan keperawatan yang berguna untuk kepentingan klien, perawat, dan tim kesehatan dalam memberikan pelayanan kesehatan dengan dasar komunikasi yang akurat dan lengkap secara tertulis dengan tanggung jawab perawat (Hidayat, 2002).

Dokumentasi asuhan keperawatan adalah suatu dokumen atau catatan yang berisi data tentang keadaan pasien yang dilihat tidak saja dari tingkat kesakitan, akan tetapi juga dilihat dari jenis, kualitas dan kuantitas dari layanan yang telah diberikan perawat dalam memenuhi 
kebutuhan pasien (Ali, 20101). Dokumentasi asuhan keperawatan adalah rangkaian kegiatan yang dilakukan oleh perawat dimulai dari proses pengkajian, dan masalah keperawatan, rencana tindakan tindakan keperawatan dan evaluasi yang dicatat baik berupa elektronik maupun manual serta dapat dipertanggungjawabkan oleh perawat.

Pendokumentasian adalah sebagai alat komunikasi, mekanisme pertanggung gugatan dan sebagai edit pelayanan keperawatan (Hidayat, 2009; Purwanti 2012; Nurman, 2013). Pendokumentasian yang efektif dan efisien dapat meningkatkan mutu pelayanan keperawatan yang dirasakan oleh klien. Pendokumentasian asuhan keperawatan wajib lengkap dan sesuai standar karena merupakan penghubung untuk mengetahui perkembangan kesehatan pasien, oleh karena itu melengkapi dokumentasi asuhan keperawatan adalah kewajiban seorang perawat.

\section{Tujuan Dokumentasi Keperawatan}

Dokumentasi keperawatan mempunyai tujuan yang sangat penting dalam bidang keperawatan titik berikut ini adalah beberapa pendapat mengenai tujuan dokumentasi keperawatan :

Menurut Nursalam (2001), tujuan utama dari dokumentasi keperawatan adalah :

a. Menginformasikan data pada semua anggota tim kesehatan.

b. Memberikan bukti untuk tujuan evaluasi asuhan keperawatan.

c. Sebagai tanggung jawab dan tanggung gugat.

d. Sebagai metode pengembangan ilmu keperawatan.

Menurut Serri (2010), tujuan dokumentasi keperawatan adalah :

a. Sebagai bukti kualitas asuhan keperawatan.

b. Bukti legal dokumentasi sebagai pertanggungjawaban perawat kepada pasien.

c. Menjadi sumber informasi terhadap perlindungan individu.

d. Sebagai bukti aplikasi standar praktik keperawatan.

e. Sebagai sumber informasi statistik untuk standar dan riset keperawatan.

f. Dapat mengurangi biaya informasi terhadap pelayanan kesehatan.

g. Sumber informasi untuk data yang harus dimasukkan dalam dokumen keperawatan yang lain sesuai dengan data yang dibutuhkan.

h. Komunikasi konsep risiko asuhan keperawatan. 
i. Informasi untuk peserta didik keperawatan.

j. Menjaga kerahasiaan informasi klien.

k. Sebagai sumber data perencanaan pelayanan kesehatan di masa yang akan datang.

Menurut Isti (2009), tujuan utama dokumentasi keperawatan adalah :

a. Sebagai sarana komunikasi.

b. Sebagai tanggung jawab dan tanggung gugat.

c. Sebagai informasi statistik.

d. Sebagai sarana pendidikan.

e. Sebagai sumber data penelitian.

f. Sebagai jaminan kualitas pelayanan kesehatan.

g. Sebagai sumber data perencanaan asuhan keperawatan berkelanjutan.

\section{Prinsip-Prinsip Dokumentasi Keperawatan}

Dalam membuat dokumentasi harus memperhatikan aspek-aspek keakuratan data, breafity (ringkas) dan legality (mudah dibaca). Adapun prinsip-prinsip dalam melakukan dokumentasi yaitu:

a. Dokumen merupakan suatu bagian integral dari pemberian asuhan keperawatan.

b. Praktik dokumentasi bersifat konsisten.

c. Tersedianya format dalam praktik dokumentasi.

d. Dokumentasi hanya dibuat oleh orang yang melakukan tindakan atau mengobservasi langsung pasien.

e. Dokumentasi harus dibuat sesegera mungkin.

f. Catatan harus dibuat secara kronologis.

g. Penulisan singkatan harus menggunakan istilah yang sudah berlaku umum dan seragam.

h. Tuliskan tanggal, dan tanda tangan dan inisial penulis.

i. Catatan harus akurat, benar, komplit, jelas ringkas Dapat dibaca dan ditulis dengan tinta.

j. Dokumentasi adalah rahasia harus disimpan dengan benar. 
Selanjutnya Potter dan Perry (1994) memberikan panduan sebagai petunjuk cara mendokumentasikan yang benar, sebagai berikut:

a. Jangan menghapus dengan menggunakan cairan penghapus atau mencoret-coret tulisan yang salah ketika mencatat, karena akan tampak perawat seakan-akan menyembunyikan informasi atau merusak catatan. Adapun cara yang benar adalah dengan membuat garis lurus pada tulisan yang salah (usahakan tulisan yang salah masih bisa dibaca), lalu diparaf pada bagian terakhir kalimat yang salah kemudian diikuti dengan tulisan kata yang benar.

b. Jangan menulis komentar yang bersifat mengkritik pasien atau tenaga kesehatan lainnya, karena pernyataan tersebut dapat dinilai sebagai Perilaku tidak profesional atau asuhan keperawatan yang tidak bermutu.

c. Koreksi semua kesalahan sesegera mungkin.

d. Bila kesalahan tidak segera diperbaiki maka dapat menyebabkan kesalahan tindakan.

e. Catatan harus akurat, valid dan reliable. Pastikan penulisan ditulis adalah fakta, jangan berspekulasi atau menuliskan pikiran sendiri.

f. Jangan biarkan pembagian kosong pada catatan perawat, karena orang lain dapat menambahkan Informasi yang tidak benar pada bagian yang kosong tersebut.

g. Semua catatan harus dapat dibaca dan ditulis dengan tinta.

h. Menulis hanya untuk diri sendiri karena Bertanggung gugat atas informasi yang telah ditulisnya. Jangan menulis untuk orang lain.

i. Hindari Penggunaan istilah yang bersifat tidak umum.

j. Memulai dokumentasi dengan waktu dan akhiri dengan tanda tangan dan nama yang jelas.

\section{- Relasi Supervisi Dengan Pendokumentasian Asuhan Keperawatan}

Tujuan dilakukan supervisi adalah mengorientasi staf dalam pelaksanaan asuhan keperawatan, memberikan arahan Dalam pelaksanaan tugasnya agar menyadari dan mengerti terhadap peran dan fungsi sebagai staf dan pelaksanaan asuhan keperawatan, memberi layanan kemampuan staf dan pelaksanaan dokumentasi keperawatan dalam memberikan asuhan serta mengusahakan seoptimal Mungkin kondisi kerja yang nyaman (Kemkes, 2010). 
Tanggung jawab kepala ruangan menurut Gillies (1994) adalah kepala ruangan harus lebih peka terhadap anggaran rumah sakit dan kualitas pelayanan kesehatan, bertanggung jawab terhadap hasil dari pelayanan keperawatan yang berkualitas. Dan menghindari terjadinya kebosanan perawat serta menghindari kemungkinan terjadinya saling melempar kesalahan. Kepala ruangan di sebuah ruangan keperawatan, perlu melakukan kegiatan koordinasi unit yang menjadi tanggung jawabnya dan melakukan kegiatan evaluasi kerja staf dalam upaya mempertahankan kualitas pelayanan kesehatan sebagai pemberi asuhan keperawatan.

\section{Pada Jurnal Pengaruh Supervisi Terhadap Kelengkapan Dokumentasi Asuhan} Keperawatan di Ruangan Non Bedah (Fitrianola Rezkiki \& Annisa Ilfa, 2018) didapat hasil penelitian Kelengkapan Dokumentasi Asuhan Keperawatan Sebelum Supervisi dan Kelengkapan Dokumentasi Asuhan Keperawatan Sesudah Supervisi di ruangan interne RSUD Padang Pariaman yang diambil secara purposive sampling. Kelengkapan dokumentasi asuhan keperawatan sebelum dilakukan supervisi didapatkan nilainya adalah 70,27\% dari $(100 \%)$ yang menuliskan dokumentasi asuhan keperawatan. Dalam tahapan pendokumentasian asuhan keperawatan masih ada beberapa point yang belum maksimal dilakukan oleh perawat seperti perencanaan dan catatan asuhan keperawatan yang sering menjadi kendala dalam pencatatan dokumentasi asuhan keperawatan secara lengkap.

Kemudian hasil yang didapat pada kelengkapan dokumentasi asuhan keperawatan sesudah supervisi adalah bahwa terdapat $82,27 \%$ kelengkapan dokumentasi asuhan keperawatan yang dilakukan oleh perawat. Terjadi peningkatan dalam kelengkapan dokumentasi asuhan keperawatan yang dilakukan perawat sesudah dilakukan supervisi yaitu sebanyak 12\%, dimana dari tahap pengkajian sampai catatan asuhan keperawatan, yang sebelumnya pada tahap perencanaan dan catatan asuhan keperawatan dalam rumusan tujuan mengandung komponen pasien, perubahan, perilaku, kondisi pasien keluarga, serta dalam melakukan tindakan/kegiatan perawat jarang mencantumkan secara lengkap paraf/nama jelas, tanggal dan jam dilakukan tindakan, sesudah dilakukan supervisi terdapat peningkatan dalam kategori tersebut.

Pada Jurnal hubungan kepemimpinan dan supervisi dengan kinerja perawat pelaksana dalam pendokumentasian asuhan keperawatan (Mursidah Dew dan Rizka Zestin, 2014) didapatkan kepemimpinan yang kurang efektif maka kinerja perawat pelaksana dalam pendokumentasian asuhan keperawatan kurang $(71,4 \%)$ proporsi ini lebih besar dibandingkan 
dengan perawat pelaksana yang menyatakan kepemimpinan efektif $(28,6 \%)$. Hasil analisis bivariat didapat $p$ value 0,001 ( $p$ value $<0,05$ ), ada hubungan yang bermakna kepemimpinan dengan kinerja perawat pelaksana dalam pendokumentasian asuhan keperawatan.

\section{Pada Jurnal Hubungan Kemampuan Supervisi Kepala Ruangan dengan Pelaksanaan} Dokumentasi Asuhan Keperawatan (David Ginting dan Yesika Widiawati Harahap, 2019). Hasil analisis menunjukkan bahwa dari 25 orang, kemampuan supervisi kepala ruangan baik dengan pelaksanaan dokumentasi asuhan keperawatan baik sebanyak 10 orang (40,0\%). Kemampuan supervisi kepala ruangan baik dengan pelaksanaan dokumentasi asuhan keperawatan baik sebanyak 10 orang $(40,0 \%)$. Berdasarkan hasil uji statistik dengan menggunakan uji Chi Squere menunjukkan bahwa $p$ value $(=0.041)<\alpha(=0,05)$. Maka dapat disimpulkan bahwa Ha diterima yaitu ada hubungan kemampuan supervisi kepala ruangan dengan pelaksanaan dokumentasi asuhan keperawatan di Ruangan Rawat Inap Rumah Sakit Grandmed Lubuk Pakam Tahun 2019.

Penelitian Etlidawati (2012) menyatakan bahwa kegiatan supervisi dengan kelengkapan dokumentasi asuhan keperawatan yang dilakukan di ruang rawat RSUD Pariaman, dari 86 responden mengatakan baik $(59,3 \%)$. Baiknya struktur supervisi kepala ruang tergambar dari kepala ruang sering memberikan penjelasan yang mudah dimengerti tentang dokumentasi, menilai asuhan keperawatan, membuat rencana pelaksanaan, serta sering memberikan penilaian hasil supervisi.

Penelitian Lestari (2014) menunjukkan bahwa kelengkapan dokumentasi asuhan keperawatan setelah dilakukan supervisi menjadi semakin baik dan lengkap. Kelengkapan dokumentasi di masing-masing bagiannya menunjukkan peningkatan, dari dokumentasi pengkajian sebanyak (87,20\%), diagnosa dan intervensi sebanyak (94,28\%), implementasi $(87,5 \%)$ dan evaluasi $(81,49 \%)$. Untuk hasil kelengkapannya terdapat $71,4 \%$ perawat yang menuliskan dokumentasi secara lengkap dan $28,6 \%$ perawat yang tidak menuliskan dokumentasi secara lengkap.

Selain itu itu menurut penelitian (Anggeria dan Maria, 2018) menunjukkan pentingnya hubungan supervisi dalam pendokumentasian yang dilakukan perawat sehingga akan meningkatkan mutu pelayanan keperawatan termasuk dalam pendokumentasian asuhan keperawatan. Berdasarkan hasil tersebut diketahui bahwa penelitian pengaruh supervisi dengan kelengkapan dokumentasi asuhan keperawatan dapat meningkatkan kelengkapan dokumentasi Asuhan Keperawatan yang dilakukan oleh perawat di ruang dan bedah. 
Menurut asumsi penelitian ada hubungan supervisi dengan pendokumentasian asuhan keperawatan, karena pendokumentasian asuhan keperawatan merupakan salah satu tugas dan tanggung jawab perawat sebagai pemberi asuhan keperawatan, mempunyai nilai hukum dan salah satu indikator menilai mutu pelayanan kesehatan rumah sakit. Penerapan pendekatan manajemen yang ditujukan untuk memantau pendokumentasian asuhan keperawatan adalah kegiatan supervisi yang dapat dilakukan oleh kepala ruang. Adanya supervisi diharapkan akan berpengaruh pada pendokumentasian yang benar pada proses keperawatan, maka bukti secara profesional dan legal dapat dipertanggungjawabkan. Oleh karena itu pelaksanaan pendokumentasian merupakan aspek yang harus diperhatikan sehingga apa yang telah dilaksanakan telah tercatat dengan baik dan benar (Setyowaty \& Kemala Rita, 2008).

Menurut teori supervisi terhadap pendokumentasian asuhan keperawatan merupakan kegiatan yang perlu dilakukan terhadap perawat pelaksana. Perlu dijaga, dibina dan ditingkatkan sikap positif nya terhadap pekerjaannya. Sikap positif perawat terhadap pekerjaannya akan tercapai apabila diberikan motivasi bimbingan dan penghargaan terhadap hasil kerjanya yang akan menciptakan kepuasan kerja perawat. Kepuasan kerja perawat pada praktik keperawatan tercapai apabila perawat merasa telah memberikan konstribusi dianggap penting, mendapat dukungan dari sumber-sumber yang ada dan out-come keperawatan banyak tercapai.

\section{PENUTUP}

\section{KESIMPULAN}

Perawat dipandang memiliki tugas dan fungsi yang sangat kompleks mulai dari fungsi independen, fungsi dependen dan fungsi interdependen, fungsi tersebut tentu harus dilaksanakan dengan sungguh-sungguh untuk mencapai tujuan mulia dan membangun citra perawat yang ideal yang identik disandingkan dengan keprofesionalan kerja perawat.

Dokumentasi keperawatan merupakan hal krusial sebagai bukti dan penanggung jawaban atas tindakan keperawatan. Setiap detail tindakan keperawatan harus dilakukan dengan baik dan benar penuh dengan tanggung jawab sesuai dengan kompetensi masingmasing perawat (Ponco, 2016).

Supervisi bertujuan untuk mengusahakan lingkungan dan kondisi kerja secara optimal mungkin termasuk suasana kerja di antara staf, dan memfasilitasi penyedia alat-alat yang 
dibutuhkan baik kualitas maupun kuantitas sehingga memudahkan untuk melaksanakan tugas. Lingkungan kerja harus diupayakan agar staf merasa bebas untuk melakukan yang terbaik yang dapat dilakukan oleh staf.

Pendokumentasian yang efektif dan efisien dapat meningkatkan mutu pelayanan keperawatan yang dirasakan oleh pasien. Pendokumentasian asuhan keperawatan wajib lengkap dan sesuai dengan standar karena merupakan penghubung untuk mengetahui perkembangan kesehatan pasien, oleh karena itu melengkapi dokumentasi asuhan keperawatan adalah kewajiban seorang perawat.

Dapat dibuktikan dari beberapa jurnal penelitian yang telah dibahas diatas, didapat bahwa supervisi dengan pendokumentasian asuhan keperawatan memiliki hubungan yang membawa perubahan postif dalam kegiatan pendokumentasian perawat pelaksana.

\section{DAFTAR PUSTAKA}

1. Andriani,Marlina.2017.Hubungan Supervisi Kepala Ruangan Dengan Pendokumentasian Asuhan Keperawatan di Ruangan Rawat Inap RSI IBNU SINA BukitTinggi.Jurnal 'Afiyah, Vol IV(2),18-24.

2. Anggeria,Elis.,Maria.2018.Hubungan Supervisi Dengan Pelaksanaan Asuhan Keperawatan di Ruang Rawat Inap Lantai 10 Rumah Sakit Umum Royal Prima Medan Tahun 2017.Jurnal JUMATIK, Vol 3(2),7897.

3. Basri.2018.Hubungan Supervisi Kepala Ruangan Terhadap Kepuasan Kerja Perawat Pelaksana di Rumah Sakit Imelda Medan.Jurnal Maternitas Kebidanan, Vol 3(2),91-106.

4. Dewi,Mursidah.,Riska Zestin.2014.Hubungan Kepemimpinan dan Supervisi Dengan Kinerja Perawat Pelaksana Dalam Pendokumentasian Asuhan Keperawatan.Jurnal Managemen Keperawatan, Vol 2(1),13-21.

5. Etlidawati.2012.Hubungan Strategi Supervisi Kepala Ruang Dengan Motivasi Perawat Dalam Pelaksanaan Pendokumentasian Asuhan Keperawatan di Ruang Rawat Inap Rumah Sakit Daerah Pariaman [artikel].Padang (ID):Program Magister Ilmu Keperawatan Kekhususan Kepemimpinan dan Manajemen Keperawatan Aliansi Universitas Indonesia-Universitas Andalas. 
6. Ginting,David.,Yesika Widiawati Harahap.2019.Hubungan Kemampuan Supervisi Kepala Ruangan Dengan Pelaksanaan Dokumentasi Asuhan Keperawatan.Jurnal Keperawatan dan Fisioterapi (JKF), Vol 1(2),36-41.

7. Harmatiwi,Dini Desi,dkk.2017.Evaluasi Pelaksanaan Supervisi Keperawatan di Rumah Sakit Umum Daerah Panembahan Senopati Bantul.Jurnal Medicoeticolegal dan Manajemen Rumah Sakit, Vol $6(1), 47-54$.

8. Mardhiah,Ainal.,Muhammad Yusuf.2018.Persepsi Perawat Pelaksana Tentang Supervisi Langsung Kepala Ruang Dalam Pelaksanaan Pendokumentasian Keperawatan.JIM FKEP, Vol III(3), 298-307.

9. Olfah,Yustiana.,Abdul Ghofur.2016.Modul Bahan Ajar Cetak Kebidanan: Dokumentasi Keperawatan.Kebayoran Baru Jakarta Selatan: Kementrian Kesehatan Republik Indonesia.

10. Prima,Rezi.2020.Hubungan Supervisi Kepala Ruang Terhadap Kinerja Perawat Pelaksana.Jurnal Kesehatan, Vol 11(1),46-51.

11. Puspitasari,Nur Wahyu,dkk.2018.Supervisi Klinik Dalam Pelayanan Keperawatan Sebagai Upaya Peningkatan Kompetensi Perawat di Rumah Sakit.Jurnal Perawat Indonesia, Vol 2(2),51-61.

12. Rezkiki,Fitrianola.,Annisa Ilfa.2018.Pengaruh Supervisi Terhadap Kelengkapan Dokumentasi Asuhan Keperawatan di Ruang Non Bedah.Real in Nursing Journal (RNJ) Vol 1(2),67-76.

13. Rum, Malihah Ramadhani.2019.Faktor-Faktor yang Mempengaruhi Kepatuhan Perawat dalam Pendokumentasian Asuhan Keperawatan.Jurnal Ilmiah Kesehatan,Vol 18(1),4-9.

14. Saputra,Muhamad Andika Sasmita,dkk.2019.Mentoring Kepala Ruangan Meningkatkan Kepatuhan Perawat Dalam Pendokumentasian Asuhan Keperawatan.Jurnal 'Aisyiyah Medika, Vol 3(2),168-182.

15. Saragih,Masri.2018.Hubungan Pelaksanaan Supervisi Kepala Ruangan Dengan Kinerja Perawat Pelaksana Dalam Pendokumentasian Askep.Jurnal Mutiara Ners, Vol 1(1),65-72.

16. Silawati,Triana.2014.Hubungan Antara Supervisi Kepala Ruang Dengan Kelengkapan Dokumentasi Asuhan Keperawatan di Ruang Rawat Inap RS Nur Hidayah Bantul [naskah publikasi].Yogyakarta 
(ID): Program Studi Ilmu Keperawatan Sekolah Tinggi Ilmu

Keperawatan 'Aisyiyah Yogyakarta.

17. Simamora, R. (2009). Dokumentasi Proses Keperawatan.

18. Simamora, R. H., Purba, J. M., Bukit, E. K., \& Nurbaiti, N. (2019).

Penguatan Peran Perawat Dalam Pelaksanaan Asuhan Keperawatan Melalui Pelatihan Layanan Prima. JPPM (Jurnal Pengabdian Dan Pemberdayaan Masyarakat), 3(1), 25-31.Pengertian dokumentasi Keperawatan, Dasar pelaksanaan dokumentasi keperawatan,Manfaat dokumentasi keperawatan, Model dokumentasi keperawatan, Karakteristik dan prinsip dokumentasi keperawatan.

19. Tajriani,Khoerur Ayi.2019.Hubungan Pengawasan Kepala Ruang Dengan Pendokumentasian Asuhan Keperawatan DI Ruang Rawat Inap Kelas II dan III RS PKU Muhammadiyah Gombong [skripsi].Gombong (ID): Program Studi S1 Keperawatan Sarjana Sekolah Tinggi Ilmu Kesehatan Muhammadiyah Gombong.

20. Wahyuni,Erna Dwi,dkk.2019.Faktor yang Berhubungan dengan Mutu Pendokumentasian Asuhan Keperawatan.Fundamental and Management Nursing Journal, Vol 2(1),16-23.

21. Wirawan,Emanuel Agung,dkk.2013.Hubungan Antara Supervisi Kepala Ruang Dengan Pendokumentasian Asuhan Keperawatan di Rumah Sakit Umum Daerah Ambarawa.Jurnal Managemen Keperawatan, Vol $1(1), 1-6$. 